\title{
MIESTUTKIMUS TULEE, oletko valmis (aikuiskasvatus)?
}

Luennoidessani jokin aika sitten eräässä yliopistossa, satuin poikkeamaan aiheestani miestutkimukseen. Poikkeaminen johtui ensikädessä siitä, että olin edellisenä iltana lukenut aihetta käsittelevän antologian ja hiukan innostunut siitä. Aihe sai aikaan yllättävän reaktion: yleisöstä kysyttiin ja ihmeteltiin, että pitääkö kaikkea ryhtyä tutkimaan, eikö joitain asioita voisi jättää silleen? Kysymys toi esiin sen, mikä aiheen pohtimisessa nimenomaan on rankkaa: sukupuolen ja sukupuolten välisen suhteen kyseenalaistamisen. Sukupuolisuuden kysyminen, jonka omassa päivittäisessä keskiverto heterotodellisuudessaan elää ajattelematta, tekee myös miestä käsittelevien kirjojen lukemisesta vaativan tehtävän. Seuraavassa luon silmäyksen muutamiin miestä, mieheyttä, maskuliinisuutta ja miehen olemusta käsitteleviin kirjoihin. Aloitan kuitenkin muutamalla naistutkimusta koskevalla kommentilla.

Kaikki approbaturin metodikurssin käyneet tietävät kuinka merkittävä muuttuja sukupuoli on ollut ja on yhteiskuntatieteellisissä tusinatutkimuksissa. Sukupuolen mukaan ollaan opittu ristiintaulukoimaan, sukupuolella ollaan selitetty milloin mitäkin sosiaalista tosiasiaa. Silti sukupuoli ei ole ollut paljon muita kummempi mitattava suure.

Sukupuolen huomioivan tutkimuksen varsinainen alku ei ole tässä ilmiötä mittaamaan pyrkivässä perinteessä, vaan emansipatorisen tiedonintressin ohjaamassa naistutkimuksessa. Kun miestutkimusta taustoitetaan, seuraavat kaksi naistutkimuksen esille nostamaa ajatusta ovat keskeisiä. Naistutkimuksen kautta ollaan ensinnäkin opittu huomaamaan, että elämme sukupuolitetussa hegemonisen maskuliinisuuden maailmassa.

Sosiaalisen todellisuuden sukupuolitus ei kuitenkaan koske jokaista naista, kaikki naiset eivät ole alistettuja. Pikemminkin sekä naisten saavuttamat sosiaaliset asemat, ehkäpä omaksumalla miehelle ominainen sukupuolirooli, että naiseus ja sen kulttuuriset merkitykset vaihtelevat, ja tutkimuksen ja intressien yhteistä kohdetta, muuten kuin hyvin yleisessä mielessä, on vaikea paikantaa. Tämä oivallus on keskeinen miestutkimukselle: Yhtä vähän kuin naista, voi miestäkään tutkimuskohteena määritellä jonkinlaisen yleisen mieheyden suunnasta. Miehiä kuten naisia on moneksi statukseltaan erilaiseksi yhteiskunnalliseksi toimijaksi, vaikka miehelle tarjoutuvia vakiintuneita rooliodotuksia, sosiaalista toimintaa ohjaavia sääntöjä, olisikin tarjolla kuinka runsaasti tahansa.

Toiseksi naistutkimuksen metodologinen oivallus genderistä, sosiaalisesta sukupuolesta, on ollut kauaskantoinen ja monella tavalla avartava. Ajatuksen mukaan emme pelkästään, emmekä kovinkaan merkityksellisesti, edusta biologisesti jompaa kumpaa sukupuolta, sex, vaan ennen kaikkea ja ensikädessä olemme kasvaneet sosiaaliseen sukupuoleen, genderiin. Gender ei ole olemassa biologisesti, vaan se on yhteiskunnallinen tosiseikka, joka saa voimakasta vahvistusta kaikista sosiaalisista käytänteistä. Simone de Beauvoirin mukaan naiseksi ei synnytä vaan kasvetaan; vastaavasti myös mieheksi kasvetaan ja kasvatetaan, ei synnytä.

Yhteiskunnissamme vallitsevan totunnaisen sukupuoliopin voisi aikuiskasvatuksen kannalta helposti empiirisesti vahvistaa menemällä jonkin kansalaisopiston saumurikurssille ja puutyöpiiriin tai vastaavasti 
henkilöstökoulutusorganisaation johtajakoulutukseen ja tekstinkäsittelykurssille. Kiinnostava tutkielman aihe olisikin tarkastella aikuiskasvatusta sukupuoliladattujen ja sukupuolineutraalien koulutuskäytäntöjen näkökulmasta otsikolla "Siellä missä miehiä/naisia tehdään".

Kiinnostus miehiin näyttää olevan yleismaailmallista. Miestä esitellään kuin ihmeenä, joka pystyy jopa synnyttämään, kuten Reitmanin elokuvassa Junior (1994). Mies tunkeutuu huoneisiin, jotka ennen on varattu ainoastaan naisille. Miestutkimusta ollaan maailmalla tehty jo useita vuosia. Suomessa kiinnostus on kanavoitunut ennen kaikkea miehille 1992-1993 suunnatun elämäkertakilpailun Eläköön mies kautta. Suomalaisten genderkirjojen pioneereina voi kuitenkin pitää Marja-Leena Parkkisen haastattelukirjaa Mitä mies? (Elämänlanka, 1992), jossa 12 varsin eri-ikäistä ja erioloista miestä ja neljä naista kertovat miehestä, mutta eritoten Juha Nummisen tavallisiin tarinoihin perustuvia kirjoja Minä keski-ikäinen mies (WSOY, 1979) ja Sinä kypsä nainen (WSOY, 1980).

Em. elämäkertakilpailuun kertyi yhteensä 364 omaelämäkertaa, yli 20000 sivua tekstiä suomalaisesta miehestä. Pohdintansa arvoinen kysymys onkin, millaisen aineiston kanssa tutkijat ovat tekemisissä, kun lukevat miesten kirjoittamia elämäkertoja. Tutkijat ovat ottaneet todesta aineistonsa edustavuus-kysymyksen, kuka ylipäätään ryhtyy kirjoittamaan? Omaelämäkerran kirjoittamiseen ryhtyminen viittaa prosessiin, jossa "[P]itää kirjoittaa tai puhua, ei pidä ajatella pohtia miettiä eikä tuumia, tai tulee hulluksi, läsähtää istumaan kuistinportille tuijottamaan omenapuun oksien alitse metsänrajaa. Kirjoitan pahan pois itsestäni." (Pentti Saarikoski, Kirje vaimolleni, Otava, 1968, s. 88.)

Alussa oli siis omaeläkerta-aineisto, josta on koottu 12 kertomuksen antologia (Eläköön mies. toim. Mika Siimes, SKS, 1994). Siinä valitut miehet saavat puheenvuoron kertoa elämästään. Valikoimaan on otettu mukaan kilpailussa menestyneiden eri-ikäisten miesten tekstejä. Niitäkin on tosin lievästi toimitettu. Minusta tuntuu, että juuri tämä kirja on se, joka synnyttää eniten mietteitä lukijassaan. Aihe on näet sellainen, että lukemastaan hyvin todennäköisesti saa irti syviä omakohtaisia pohdintoja ja elämyksellisiä tosiasioita ilman aineiston teoretisointejakin.

Jos sitten haluaa nähdä miten tutkijamiehet ja -naiset ovat lukemaansa suhtautuneet ja miestä tarkastelleet on tarjolla kaksi teosta. J.P Roosin ja Eeva Peltosen toimittama tutkijoiden puheenvuoron Miehen elämää (SKS, 1994) artikkelit perustuvat em. omaelämäkertoihin. Jorma Sipilän ja Arto Tiihosen toimittama Miestä rakennetaan, maskuliinisuuksia puretaan (Vastapaino, 1994) sisältää monitieteisiä näkökulmia mieheyden tematiikkaan. Kumpikin ottaa aiheeseensa ainakin yhtä monta näkökulmaa kuin on kirjoittajia ja enemmänkin. Kirjoista voi löytää löyhiä tematisointeja. Edellisestä miehen suhteen kasvatukseen, seksiin, häpeään ja työttömyyteen, jälkimmäisestä hegemoniseen maskuliinisuuteen, väkivaltaan, marginaaliin ja ruumiiseen. Näiden ulkopuolella tarkastellaan mieheyttä ja maskuliinisuutta lisäksi erilaisia teoreettisia lähtökohtia painottaen. Korostuneesti esillä on kulttuurintutkimukseen sovitettu psykoanalyyttinen teoria.

Oma lukunsa miestutkimuksessa ovat Juha Siltalan (Miehen kunnia. Otava, 1994) ja Jouko Turkan (Häpeä. Otava, 1994) kirjat, joiden nimetkin tuottavat kiintoisan jännitteen. Siinä missä toinen kertoo kunniasta, viittaa toinen miehen elämän häpeään. Kun sitten lukee kirjat, ymmärtää myös termien vahvan sisällöllisen yhteyden: miehen elämä tähtää kunnian säilyttämiseen ja häpeä välttämiseen. Tämä teema saa kirjoissa lukuisia toistaan huikaisevampia muunnelmia ja sitä analysoidaan erilaisin käsitteellisin apparaatein.

Turkka jäsentää mieheyttä häpeän käsitteellä. Miehen - ainakin Turkan - elämä jäsentyy häpeän välttämisen ja kunnian säilyttämisen ambivalentille suhteelle. Häpeä nousee milloin lapsuuden traumaattisesta kokemuksesta, milloin mistäkin sosiaalisen elämän episodista: "Se on täysin yksityistä, se mikä hävettää ja jäykistää, halvaannuttaa yhden, sitä toinen ei edes tajua hävetä." Ambivalenssi ilmenee itsensä paljastamisena kelvottomana, mutta silti kaikkensa antaneena ja yrittäneenä isänä. Kaikista henkisistä rikoksista huolimatta ja "[V]aikka en ole saanut aikaan yhtään mitään koko elämäni aikana, joku rakastaa minua. Minua on ainakin kerran rakastettu. Tunnen että joku rakastaa minua!" 
Turkan kirja lienisi mainiota aineistoa Juha Siltalan harjoittamalle psykohistorialliselle tutkimukselle, jossa psykoanalyyttisen kulttuurintutkimuksen keinoin tarkastellaan ahdistuksen ja häpeän käsittelytapojen kulttuurista muuntelua. Käsillä olevassa kirjassa pyritään osoittamaan tarvitsevuuden pelon ja toisista riippumattomuuden palon merkitykset suomalaisen miehen elämää jäsentävinä peruspyrkimyksinä. Kirjan aineistona on $55 \mathrm{kpl}: t a \mathrm{em}$. miesten omaelämäkertoja ja muita miehistä kertovia kulttuurituotteita. Kirja ei ole helppoa luettavaa psykoanalyyttisesti lukutaidottomalle eikä se välttämättä stimuloi massiivisuudellaan. Silti se paikoitellen kiihottaa valmistautumatontakin mieltä pohtimaan miehisyyden olemusta ja itsestäänselvyyksien selvyyttä.

Omalla tavallaan kummassakin kirjassa luodaan silta yksilön psyykkisen rakenteen ja sitä ympäröivän sosiaaliseksi kutsutun välittäjäaineen välille. Siinä missä Siltala "kaikesta huolimatta" säilyttää otteensa tutkijan deskriptiivisenä kerrontana, osoittaa Turkka vain itseensä ja laukoo rajuja totuuksia yleisestäkin elämän menosta, siitä mitä tapahtuu todella. Tässä mielessä Turkan kirja jatkaa suomalaisten miesten kirjoittaman tunnustuskirjallisuuden (mm. Järnefeltin Heräämiseni, Sillanpään Rippi, Kihlman Ihminen joka järkkyi, Saarikosken Euroopan reuna, Donnerin Minä Jörn Johan Donner, Haavikon Yritys omaksikuvaksi) pitkää perinnettä.

Omaelämäkertoja on Suomessakin kerätty monilla eri teemoilla. Aluksi oli Roosin Suomalainen elämä (SKS, 1987), sitten tulivat erityisemmät kohteet: naiselämäkerrat, seksielämäkerrat, mieselämäkerrat. Kiinnostavaa on ollut huomata, että kasvatusta ja koulua koskevia kysymyksiä on usein sivuttu ja pohdittukin tutkijoiden teksteissä. Maininnat ovat ehkä Tommi Hoikkalaa lukuunottamatta muiden juttujen sivupolkuja. Olisikin aika järjestää elämäkertakilpailu, jossa kirjoitettaisiin kasvatuksesta, koulusta ja koulutuksesta.

Kun miestutkimus on nyt tosiasia voidaan kysyä, onko sillä mitään tekemistä aikuiskasvatuksen kanssa. jos optimistisesti ajateltaisiin, että aikuiskasvatuksen piirissä oltaisiin jollain tavoin kiinnostuneita yhteisistä asioista, voitaisiin myös huomata, että miestutkimus ajoittuu yhteiskunnalliseen tilanteeseen, jossa politiikan ja yhteiskunnallisten liikkeiden asettamista ongelmista ollaan siirrytty yksilöllisen identiteetin rakentamisen pulmiin. Sukupuolesta on tullut yksilöä rakentava ja jäsentävä kategoria sosiaalisten ja kollektiivisten tilalle. Tyhjäksi jäänyttä sosiaalista tilaa täytetään sukupuoleen liittyvillä kysymyksillä. Se, mitkä ovat yhteiskunnallisesti anomaalisen kehityksen seuraukset, jää nähtäväksi.

Tilanteessa, jota voi kutsua yksilöityneeksi yhteiskunnaksi, mieskirjat opettavat silmättömänkin näkemään, että miehuutta voidaan rakentaa lukemattomilla tyyleillä ja maskuliinisuuden malleja on useampia kuin yksi. Niin paljon kuin kirjat vahvistavatkin stereotyyppistä suomalaista mieskuvaa, näyttävät ne myös miesten moneuden, samalla miehen elämän tulkintarikkauden. Kirjojen kautta maailmaa alkaa tarkastella uudesta näkökulmasta: miesten moneus esittäytyy Esa Sariolan kuunnelmissa, romaaneissa, kaduilla, on miehiä elämänsä alussa ja taipaleensa loppupuolella, tosihemmoja ja sodan käyneitä, parasta A-ryhmää, monimuotoisesti seksuaalisia miehiä ja ikuisia partiopoikia.

Kirjojen keskeisin sanoma onkin se, että mieheys ja maskuliinisuus eivät ole yksi ja yhtenäinen kulttuurinen nimeämiskäytäntö, joka naulitsee jokaisen pojan syntymästään yhden miehen mallin mukaiseen kulttuuriseen ristiin. Maskuliinisuuksissakin on vaihtelevuutta sen suhteen kuka nauttii yhteiskunnallisista ja muista etuoikeuksista, kuka taas ei. Kysymys on eroista, siksi kysymys on yhteisistä asioista. 